\title{
The Prenatal Diagnosis of Adrenoleukodystrophy. Demonstration of Increased Hexacosanoic Acid Levels in Cultured Amniocytes and Fetal Adrenal Gland
}

\author{
HUGO W. MOSER, ${ }^{(18)}$ ANN B. MOSER, JAMES M. POWERS, HAROLD M. NITOWSKY, \\ HERBERT H. SCHAUMBURG, ROBERT A. NORUM, AND BARBARA R. MIGEON

\begin{abstract}
John F. Kennedy Institute for Handicapped Children, Baltimore, Maryland; The Department of Pathology, Medical University of South Carolina, Charleston South Carolina, [J.M.P.]; The Departments of Neurology and Pediatrics, Albert Einstein College of Medicine, New York [H.M.N., H.H.S.]; Department of Medicine Henry Ford Hospital, Detroit, Michigan [R.A.N.] and Department of Pediatrics, Johns Hopkins University,
\end{abstract} \\ Baltimore, Maryland [B.R.M.]. USA
}

Summary

Amniocentesis was performed in two women heterozygous for adrenoleukodystrophy (ALD). One fetus was male, and the hexacosanoic acid $(\mathrm{C} 26)$ level in the cultured amniotic cells was 0.808 $\mu \mathrm{g}$ per $\mathrm{mg}$ of protein, compared to $0.104 \pm 0.069$ (S.D.) in controls. Pregnancy was interrupted at 22 wk gestation. The fetal adrenal cortex showed the ultrastructural inclusions characteristic of ALD and $\mathrm{C} 26$ accounted for $35 \%$ of the fatty acids in the cholesterol esters extracted from this tissue, more than one thousand times control. The second amniocentesis was performed in a woman who was also heterozygous for an electrophoretic variant of glucose 6phosphate dehydrogenase (G6PD), and a member of a kindred showing genetic linkage of loci for ALD and G6PD. The fetus was female and the $C 26$ level in cultured amniotic cells was 0.577 . Pregnancy was interrupted at 11 wk for reasons unrelated to ALD. Study of C26 level and G6PD type in cultured fetal tissues confirmed heterozygosity for ALD.

\section{Speculation}

The capacity to identify the adrenoleukodystrophy (ALD) hemizygote prenatally together with the availability of tests of plasma and/or cultured skin fibroblasts, which can identify most women heterozygote for this disorder, provide the opportunity for families at risk for ALD to have normal children. It is striking that the fetal adrenal was already abnormal, because clinical evidence of adrenal insufficiency would not have been expected until more than 4 years postnatally. Because the abnormal fatty acids are of dietary origin at least in part, it may be possible to diminish or prevent their accumulation by reducing their intake.

Adrenoleukodystrophy (ALD) is an X-linked disorder associated with progressive demyelination, diminished adrenal function, and characteristic cytoplasmic inclusions (11). A milder adult form of the disease (adrenomyeloneuropathy) has also been described (12). Increased levels of saturated very long chain fatty acids, particularly hexacosanoic acid (C26), have been demonstrated in the cholesterol ester fraction of adrenal cortex and cerebral white matter (3), in total lipids and sphingolipids of cultured skin fibroblasts (7) and muscle cells (2), and in the plasma (9) and red blood cells (15). Studies of persons heterozygous for both ALD and an electrophoretic variant of glucose 6-phosphate dehydrogenase (G6PD) have revealed that the ALD and the G6PD loci are closely linked and can be mapped on the human $\mathrm{X}$ chromosome at $\mathrm{X}_{\mathrm{q}} 28(6)$. We have shown recently that patients with ALD have an impaired capacity to oxidize very long chain fatty acids (14).

\section{PATIENTS AND METHODS}

Case 1. This was the first pregnancy in a 26-year-old white woman whose 16-year-old brother had died of ALD, and who had two other male relatives with this disorder on her mother's side. The C26 level in the mother's cultured skin fibroblasts was in the ALD heterozygote range (Table 1). Amniocentesis was performed at 16 wk gestation. After the amniotic fluid cell karyotype was found to be male and the C26 levels in cultured amniotic fluid cells were shown to be high, abortion was induced at 22 wk with prostaglandin.

Case 2. This was the first pregnancy in a 14-year-old woman who is a member of a large kindred with ALD, which has been reported previously (6) (Case III-14 family 3). In this family the locus for G6PD was shown to be linked to the locus for ALD. This patient was identified as an ALD heterozygote on the basis of G6PD type and C26 levels in cultured skin fibroblast clones. Amniocentesis was performed at $11 \mathrm{wk}$, immediately before induction of abortion for reasons unrelated to ALD. The amniotic fluid cell karyotype was female.

Amniotic fluid cells were grown in a $5 \%$ carbon dioxide atmosphere at $37^{\circ} \mathrm{C}$ in Eagle's minimum essential medium plus Earle's salts and $13 \%$ fetal calf serum. The cells were harvested 34 days after confluence. Lipid extraction, lipid fractionation and protein determinations were performed as described previously $(7,9)$. Fatty acid methyl esters were purified and measured with a capillary gas liquid chromatography system under conditions adapted for the quantitation of saturated and monounsaturated very long chain fatty acids (9).

\section{RESULTS}

Table 1 lists the $\mathrm{C} 22$ and $\mathrm{C} 26$ levels and the ratio of $\mathrm{C} 26$ to $\mathrm{C} 22$ fatty acids for cultured amniotic fluid cells and cultured skin fibroblasts. As we have shown previously for cultured skin fibroblasts (7), the C26 level is increased significantly whereas the C22 level is unaltered. For diagnostic purposes we have found it useful to express results as the $\mathrm{C} 26: \mathrm{C} 22$ ratio.

The $\mathrm{C} 26$ level and the $\mathrm{C} 26: \mathrm{C} 22$ ratio in cultured amniotic fluid cells of both fetuses were elevated significantly over those in 23 control cell lines. We concluded that fetus I was hemizygous and fetus 2 heterozygous for ALD. This conclusion is confirmed by data presented in Figures 1 and 2, and in Tables 2 and 3. 
Table 1. C22 and C26 levels in cultured amniotic fluid cells and skin fibroblasts ${ }^{1}$

\begin{tabular}{|c|c|c|c|c|}
\hline & $\begin{array}{c}\text { Number } \\
\text { of sam- } \\
\text { ples }\end{array}$ & $\begin{array}{c}\mathrm{C} 22(\mu \mathrm{g} / \mathrm{mg} \\
\text { protein) }\end{array}$ & $\mathrm{C} 26$ & $\mathrm{C} 26: \mathrm{C} 22$ \\
\hline \multicolumn{5}{|l|}{$\begin{array}{l}\text { Cultured amniotic } \\
\text { fluid cells }\end{array}$} \\
\hline $\begin{array}{l}\text { Proband } 1 \\
\text { (male) }\end{array}$ & & $0.99 ; 1.1$ & $0.73 ; 0.88$ & $0.74 ; 0.79$ \\
\hline Proband 2 & & $0.31 ; 0.44$ & $0.38 ; 0.78$ & $1.2 ; 1.8$ \\
\hline Control & 23 & $0.69 ; \pm 0.47$ & $0.10 \pm 0.07$ & $0.17 \pm 0.10$ \\
\hline Control range & & $0.34-2.6$ & $0.02-0.24$ & $0.06-0.44$ \\
\hline \multicolumn{5}{|c|}{ Cultured Skin fibroblasts } \\
\hline $\begin{array}{l}\text { ALD hemizy- } \\
\text { gote }\end{array}$ & 58 & $0.57 \pm 0.24$ & $0.40 \pm 0.15$ & $0.69 \pm 0.20$ \\
\hline Range & & $0.20-1.6$ & $0.14-0.98$ & $0.31-1.2$ \\
\hline $\begin{array}{l}\text { ALD heterozy- } \\
\text { gote }\end{array}$ & 33 & $0.70 \pm 0.32$ & $0.28 \pm 0.18$ & $0.40 \pm 0.23$ \\
\hline Range & & $0.27-1.4$ & $0.09-0.90$ & $0.09-1.0$ \\
\hline Control & 88 & $0.74 \pm 0.38$ & $0.07 \pm 0.04$ & $0.09 \pm 0.05$ \\
\hline Range & & $0.29-2.1$ & $0-0.24$ & $0-0.27$ \\
\hline Proband 2 & & $0.27 ; 0.26$ & $0.30 ; 0.29$ & $1.1 ; 1.1$ \\
\hline $\begin{array}{l}\text { Mother of Pro- } \\
\text { band } 1\end{array}$ & & 1.3 & 0.36 & 0.28 \\
\hline
\end{tabular}

'The listed values are means and S.D. The control cultured amniotic fluids were obtained from amniocenteses performed in pregnancies not at risk for ALD.

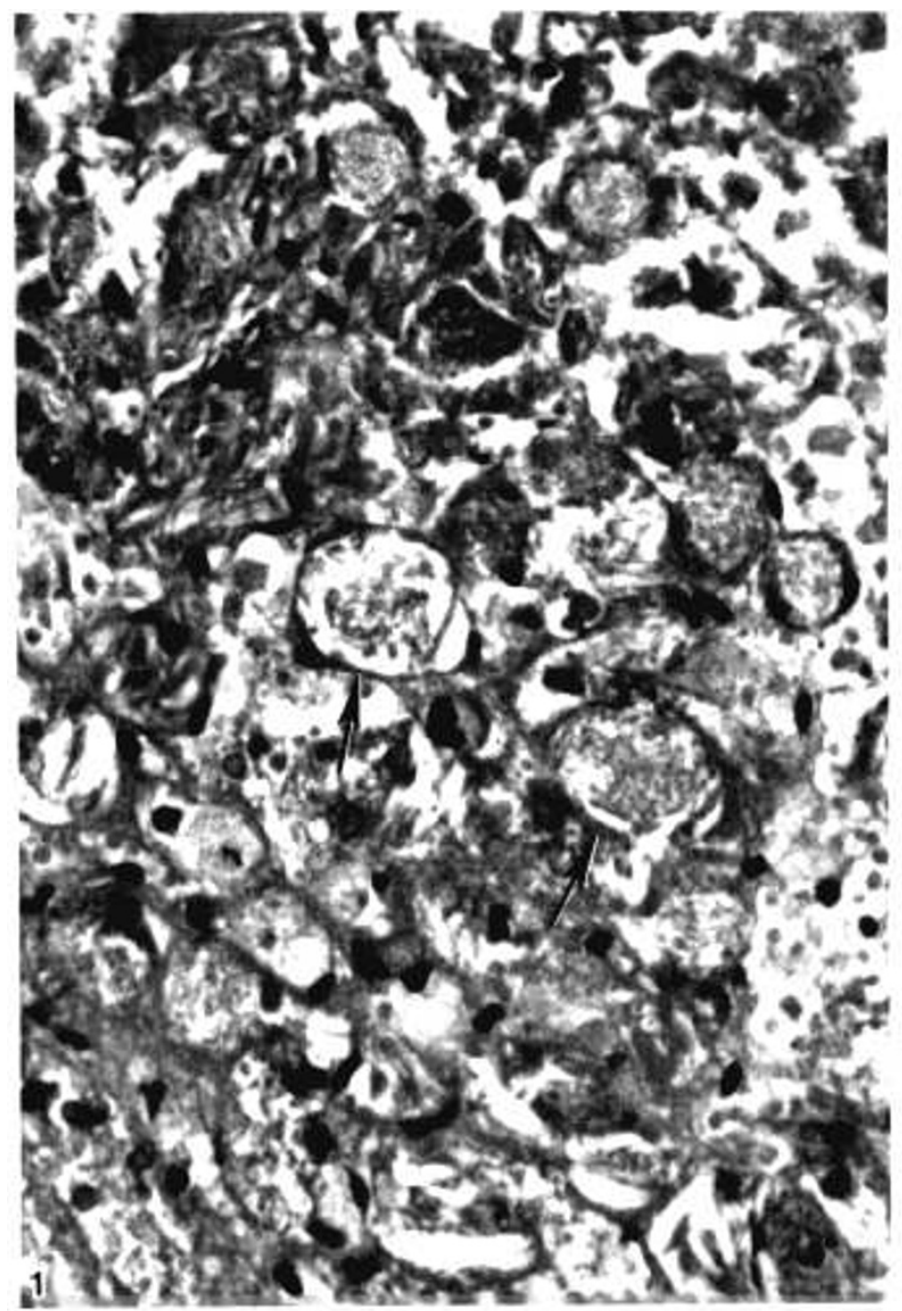

Fig. 1. Adrenal cortex of Fetus 1. The cytoplasm is ballooned and striated (arrows). Masson trichrome, $\times 600$.

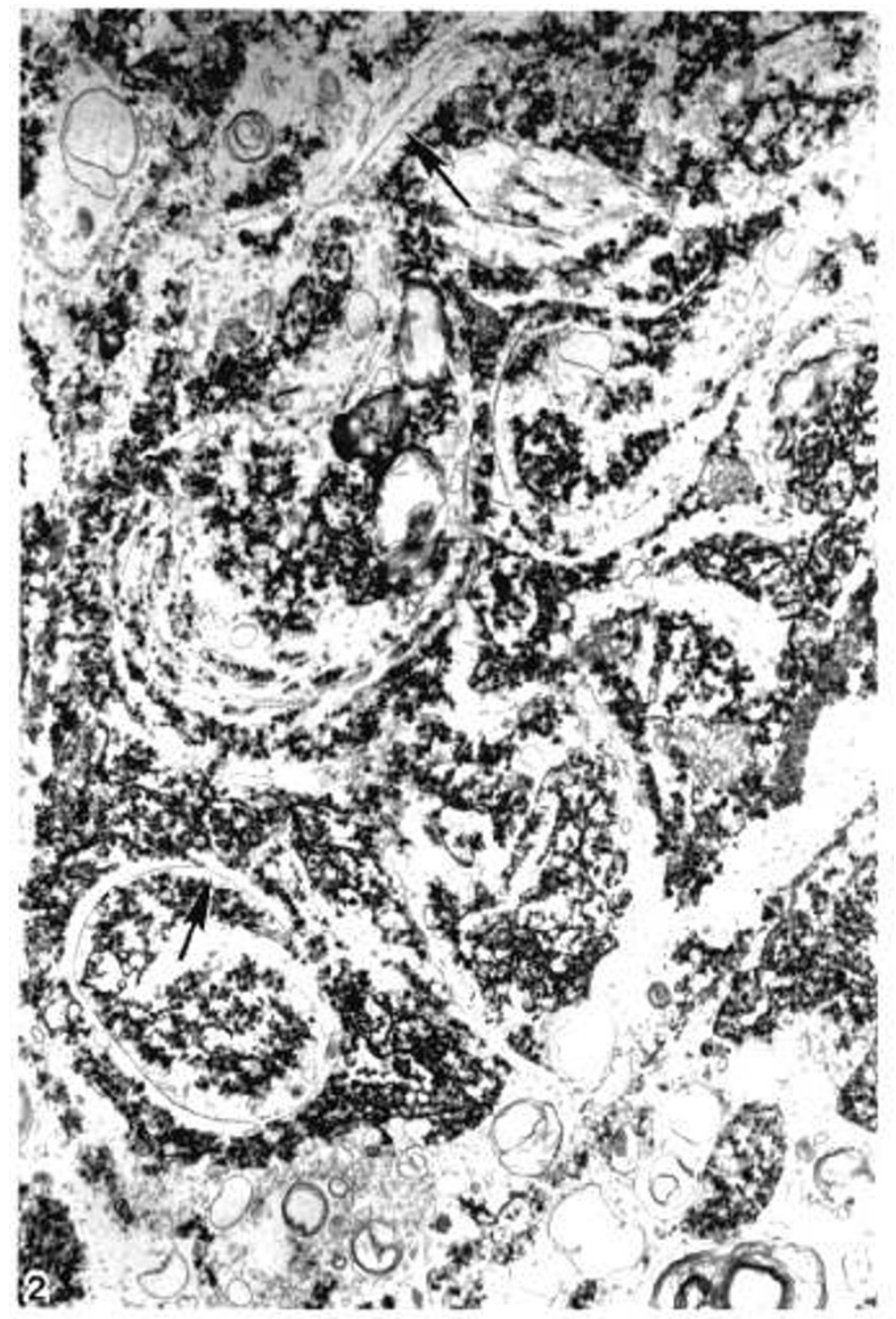

Fig. 2. Electron micrograph of fetal adrenocortical cells which contain lamellar-lipid profiles (arrows) Uranyl acetate-lead citrate, $X 8600$.

The fetal adrenal cortical cells of fetus I showed the lesion pathognomonic of ALD (Fig. 1 and 2). No morphologic abnormalities were demonstrated in the central nervous system.

Exceedingly high levels of very long chain fatty acids were present in the cholesterol ester fraction of the adrenal cortex of fetus 1 (Table 2). These levels were more than a 1000-fold higher than control, comparable to those in the postmortem adrenal of a neonatal ALD patient and higher than those reported for biopsy of postmortem adrenal tissues from classical ALD cases (columns 3 and 4, Table 2). The brain cholesterol ester fraction from fetus l contained 0.8 to $1.4 \% \mathrm{C} 26$. This is probably higher than normal but we have not studied a sufficient number of controls to permit definitive conclusions.

Although samples from fetus 2 were not available for morphologic or biochemical assays, we were able to culture several of the tissues. Table 3 shows that cultures of lung, liver, skin and brain had significantly increased levels of $\mathrm{C} 26$ and a significant increase in the C26:C22 ratio in comparison to controls. The cell lines with the greatest C26 excess also showed the G6PD A electrophoretic variant, in confirmation of our previous demonstration of a linkage between the ALD mutation and the G6PDA type in this kindred (6).

Table 1 also lists the results of the cultured skin fibroblast assay which has been described in previous publications $(7,8)$. Table 1 updates our experience with this assay through April 1981. Although the results with cultured amniotic fluid cells and skin fibroblasts show the same general trends, the C26 level in the amniotic fluid cells are 1.5-2 times higher than those in the fibroblasts. For the control $\mathrm{C} 26$ to $\mathrm{C} 22$ ratio, this difference is 
Table 2. Very long chain fatty acids in adrenal cortex cholesterol esters expressed as \% of total fatty acids

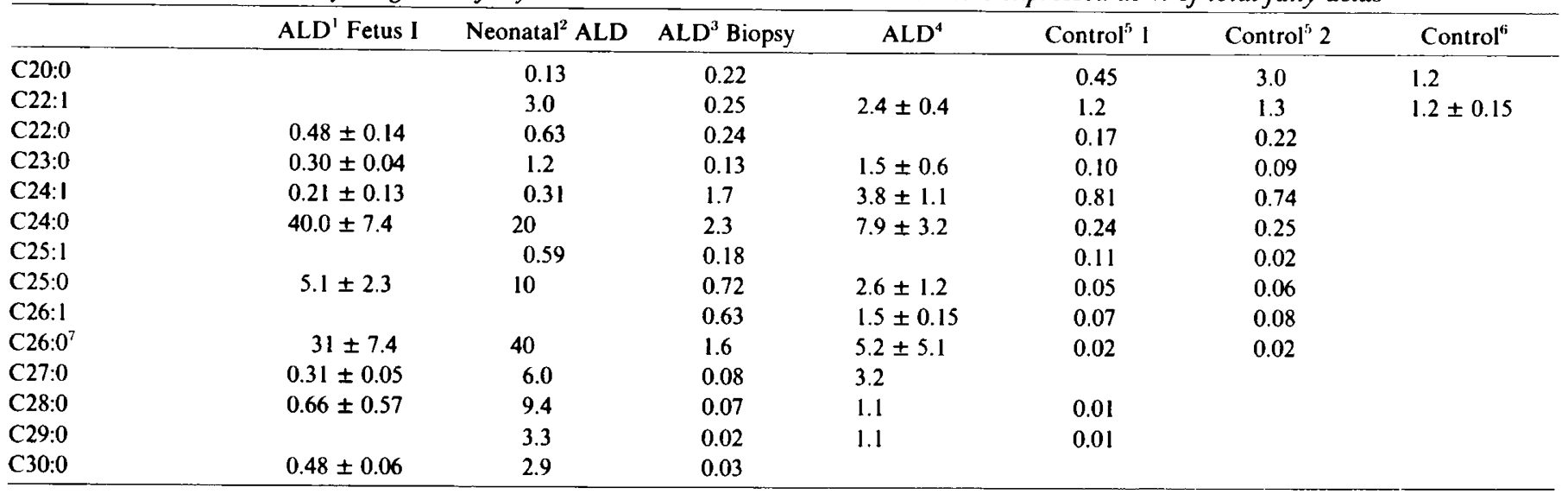

' Case 1 , mean and average deviation of mean for three determinations.

${ }^{2}$ Postmortem tissue from a $2 \frac{1}{2} 2$-year-old patient with neonatal ALD (8).

${ }^{3}$ Biopsy sample from a 9-year-old patient with typical ALD.

${ }^{4}$ Data recalculated from publication by Igarashi el al. (3); mean values of four ALD cases.

${ }^{5}$ Control postmortem adrenal glands from patients $16-18$ years old, respectively.

${ }^{6}$ Mean values for four control adrenals recalculated from Igarashi et al. (3).

' Note that C26 levels in the ALD fetal adrenal are more than 1000-fold higher than control.

Table 3. Case 2: very long chain fatty acid levels in cultured tissues

\begin{tabular}{|c|c|c|c|c|}
\hline & $\begin{array}{l}\text { G6PD } \\
\text { Type }\end{array}$ & $\begin{array}{c}\mathrm{C} 22 \\
(\mu \mathrm{g} / \mathrm{mg} \\
\text { protein })\end{array}$ & $\begin{array}{c}\mathrm{C} 26 \\
(\mu \mathrm{g} / \mathrm{mg} \\
\text { protein })\end{array}$ & $\mathrm{C} 26: \mathrm{C} 22$ \\
\hline \multicolumn{5}{|l|}{$\begin{array}{r}\text { ALD heterozygote } \\
\text { fetus (Case 2) }\end{array}$} \\
\hline Liver & A & $0.85 ; 0.43$ & $1.1 ; 0.53$ & $1.3 ; 1.2$ \\
\hline Lung & $\mathbf{A B}$ & $0.32 ; 0.44$ & $0.12 ; 0.18$ & $0.38 ; 0.41$ \\
\hline Brain & A & $0.44 ; 0.48$ & $0.42 ; 0.42$ & $0.96 ; 0.87$ \\
\hline Skin & A & $0.27 ; 0.26$ & $0.30 ; 0.29$ & $1.1 ; 1.1$ \\
\hline $\begin{array}{l}\text { Amniotic fluid } \\
\text { cells }\end{array}$ & A & $0.31 ; 0.45$ & $0.38 ; 0.78$ & $1.2 ; 1.8$ \\
\hline Control fetal tissues & $\mathrm{N}$ & & & \\
\hline Liver & 2 & $0.63 \pm 0.17$ & $0.13 \pm 0.02$ & $0.22 \pm 0.05$ \\
\hline Lung & 4 & $0.59 \pm 0.28$ & $0.12 \pm 0.07$ & $0.21 \pm 0.09$ \\
\hline Brain & 1 & 0.33 & 0.11 & 0.32 \\
\hline Skin & 4 & $0.56 \pm 0.25$ & $0.16 \pm 0.15$ & $0.26 \pm 0.18$ \\
\hline $\begin{array}{l}\text { Amniotic fluid } \\
\text { cells }\end{array}$ & 23 & $0.69 \pm 0.47$ & $0.10 \pm 0.07$ & $0.17 \pm 0.10$ \\
\hline
\end{tabular}

' Case 2 is part of a large kindred in which the G6PD electrophoretic variant $\mathrm{A}$ has been shown to be linked to the ALD mutation. In studies with cloned cells it was noted that cells with the ALD mutation and the G6PD type $A$ appeared to have a proliferative advantage (6). This phenomenon is demonstrated in cultures of the liver, brain, skin, and amniotic fluid cells of Case 2 which show G6PD type $A$ and a C26:C22 ratio in the ALD hemizygote range. In the cultured lung, cells with G6PD $A$ and G6PD B type were present in approximately equal number, and the C26: C22 ratio was in the ALD heterozygote range, indicating that in this tissue the mutant and wild type cells had proliferated at approximately equal rates. The control fetal tissues were measured in duplicate. All tissues of Case 2 showed significantly elevated C26 levels, and this finding validates the identification of this fetus as an ALD heterozygote.

significant with a $P$ value of less than 0.001 . For the $C 26$ level per $\mathrm{mg}$ of protein, the level of significance is between 0.01 and 0.05 .

\section{DISCUSSION}

The aim of prenatal studies in a serious X-linked disorder such as ALD is the identification of the unaffected male fetus, so that pregnancy can be continued with the assurance that the male child will be free of the disease. The results presented suggest that this goal can be achieved, subject to certain cautions. Demonstration in cultured amniotic fluid cells (CAFC) of C26:C22 ratios which were much higher than control CAFC ratios, and were in the range of these ratios found in cultured skin fibroblasts (CSFB) from ALD hemizygotes led to the correct identification of the presence of the ALD gene in one male and one female fetus. Perhaps even more important is the question of whether normal $\mathrm{C} 26: \mathrm{C} 22$ ratios in CAFC from a male fetus can give assurance that the fetus does not have the disease. The distribution of $\mathrm{C} 26$ : C22 ratios in CSFB from ALD hemizygotes does not overlap with the distribution from control subjects (Table 1). The finding that $\mathrm{C} 26: \mathrm{C} 22$ ratios in CAFC from two fetuses with the ALD gene were much higher than the ratios from control CAFC suggests strongly that these two distributions may also be well separated. Further experience with the measurement of fatty acids in CAFC will answer the question.

Until further data are available the selection of an upper limit to the C26:C22 ratio that will adequately classify normal males in pregnancies at risk for ALD is somewhat arbitrary, but important in advising parents. In CSFB from 400 individuals, a ratio of 0.300 separates all of the normal subjects from all the ALD hemizygotes. Table 1 shows that in CAFC the normal C26:C22 ratio may be 1.5-2 times higher than in CSFB. Because of our limited experience with assaying cultured amniocytes and the wish to avoid a false negative, we propose that at this time the discriminating ratio for CAFC be set at one standard deviation above the mean value for the $\mathrm{C} 26: \mathrm{C} 22$ ratio in the 23 control CAFC specimens- i.e., $0.17+0.103$ or 0.27 (Table 1). We believe that values below this level give a high level of assurance that the male fetus does not have ALD. It is important that the result be based upon duplicate or triplicate analyses with good replication and it should also take into account the $\mathrm{C} 26$ level expressed as micrograms per $\mathrm{mg}$ of protein. Most likely the discriminating ratio will be modified in an upward direction as we gain experience with additional pregnancies at risk for ALD.

Two additional approaches may increase the accuracy of the prenatal identification. We have shown recently that the ability to oxidize $\mathrm{C} 24$ fatty acid to $\mathrm{CO}_{2}$ is impaired significantly in cultured skin fibroblasts of ALD patients (14). If, as seems likely, this will be shown to apply also to cultured amniotic fluid cells, this or other enzymatic tests will be combined with the present assay and may even replace it. Second, we have referred previously to the fact that the G6PD and the ALD loci are in close proximity to each other on the $X$ chromosome (6). Thus if it is possible in a given kindred to establish linkage between ALD status and an 
electrophoretic variant of G6PD, then identification of the G6PD type in the fetus may provide important leads about the ALD status of the fetus.

The adrenal gland of the ALD fetus already contained the characteristic inclusions and an accumulation of very long chain fatty acids in the cholesterol ester fraction comparable or even higher than that in patients who have died of ALD. Ultrastructural abnormalities characteristic of the disease have also been demonstrated in fetuses with metachromatic leukodystrophy (5) or with Tay Sachs disease (1). The striking abnormality in the ALD fetal adrenal gland is surprising; however, biochemical or clinical evidence of adrenal insufficiency in ALD does not occur until 3 or 4 years after birth or later. In contrast to the adrenal, the ALD fetal brain tissue showed no demonstrable abnormalities. This probably relates to the fact that myelination in the human central nervous system is mainly a postnatal phenomenon whereas the fetal adrenal gland has important physiologic functions (13).

We have shown previously that the $\mathrm{C} 26$ fatty acid in the brain of an ALD patient is of dietary origin at least in part $(4,8)$. This observation has led us to initiate a therapeutic trial of a diet with restricted content of very long chain fatty acids (8). Recent studies, in which we administered deuterated water to a patient with ALD, indicate that some of the $\mathrm{C} 26$ in brain and liver was also of endogenous origin (10). Data are insufficient to decide whether the huge excess of C26 in the ALD fetal adrenal is mostly of exogenous or endogenous origin. The exogenous $\mathrm{C} 26$ would have been transferred from maternal blood. We have demonstrated that most ALD heterozygotes have abnormally high plasma levels of C24, C25 and C26 fatty acids (9). The plasma C26 in the mother of case 1 was $0.042 \%$ of total fatty acids, which is 3 times normal. If it is found feasible to lower plasma levels of very long chain fatty acids by dietary or other approaches, then it may be possible to delay or even prevent the disability associated with ALD with therapy initiated during fetal life or during the first years of life before the occurrence of symptoms.

\section{REFERENCES AND NOTES}

I. Adachi, M., Schneck, L., and Volk, B.W.: Ultrastructural studies of eight cases of fetal Tay-Sachs disease. Lab. Invest.. 30: 102 (1974).

2. Askanas, V.. McLaughlin. J., Engel, W. K., and Adornato, B. T.: Abnormalities in cultured muscle and peripheral nerve of a patient with adrenomyeloneuropathy. N. Engl. J. Med., 301: 588 (1979).

3. Igarashi, M., Schaumburg, H. H., Powers, J. M., Kishimoto, Y., Kolodny, E.. and Suzuki, K.: Fatty acid abnormality in adrenoleukodystrophy. J. Neurochem., 26: 851 (1976)

4. Kishimoto, Y., Moser, H. W., Kawamura, N., Platt, M., Pallante, B., and Fenselau, C.: Adrenoleukodystrophy: evidence that abnormal very long chain fatty acids of brain cholesterol esters are of exogenous origin. Biochem. Biophys. Res. Commun., 96: 69 (1980).

5. Leroy, J. G., Van Elsen, A. F., Martin, J. J., Dumon, J. E., Hulet, A. E., Okada S., and Navarro, C.: Infantile metachromatic leukodystrophy. Confirmation of a prenatal diagnosis. N. Engl. J. Med., 288: 1365 (1973).

6. Migeon, B. R., Moser, H. W., Moser, A. B., Sprenkle, J. A. Sillence. D., and Norum, R. A.: Adrenoleukodystrophy: evidence for X-linkage, inactivation and selection favoring the mutant allele in heterozygous cells. Proc. Natl. Acad. Sci. U.S.A., 78: 5066 (1981).

7. Moser, H. W., Moser, A. B., Kawamura, N., Murphy, J., Milunsky, A., Suzuki. K. Schaumburg. H., and Kishimoto, Y.: Adrenoleukodystrophy: elevated C26 fatty acid in cultured skin fibroblasts. Ann. Neurol., 7: 542 (1980).

8. Moser, H. W., Moser, A. B., Kawamura, N., Migeon, B. R., O'Neill, B. P. Fenselau, C.. and Kishimoto, Y.: Adrenoleukodystrophy: studies of the phenotype, genetics and biochemistry, Johns Hopkins Med. J., 147: 217 (1980).

9. Moser, H. W., Moser, A. B., Frayer, K. K., Chen, W. W., Schulman. J. D. O'Neill, B. P.. and Kishimoto, Y.: Adrenoleukodystrophy: increased plasma content of saturated very long chain fatty acids. Neurology, 3I: 1241 (1981).

10. Moser, H. W., Moser, A. B., Pallante, B., and Fenselau. C. Unpublished observation.

11. Schaumburg, H. H., Powers, J. M.. Raine, C. S., Suzuki, K., and Richardson, E. P.: Adrenoleukodystrophy. A clinical and pathological study of 17 cases Arch. Neurol., 32: 577 (1975).

12. Schaumburg, H. H. Powers, J. M. Raine, C. S. Spencer, P. S., Griffin, J. W Prineas, J. W.. and Boehme, D. M.: Adrenomyeloneuropathy: a probable variant of adrenoleukodystrophy. Neurology. 27: 1114 (1977).

13. Seron-Ferre, M, and Jaffe, R. B.: The fetal adrenal gland. Ann. Rev. Physiol., 43: 141 (1981).

14. Singh, I., Moser, H. W., Moser, A. B., and Kishimoto, Y.: Adrenoleukodystrophy: impaired oxidation of long chain fatty acids in cultured skin fibroblasts and adrenal cortex. Biochem. Biophys. Res. Commun., 102: 1223 (1981).

15. Tsuji, S.. Suzuki, M., Ariga, T.. Sekine, M., Kurijama. M., and Miyatake. T. Abnormality of Long-Chain fatty acids in erythrocyte membrane sphingomyelin from patients with adrenoleukodystrophy. J. Neurochem., 36: 1046 (1981).

16. Informed consent was obtained from all human subjects.

17. The authors thank Ms. Joyce Axelman for culturing the cells of fetus 2 and the control fetal tissues.

18. Requests for reprints should be addressed to: Dr. Hugo W. Moser, John F Kennedy lnstitute, 707 North Broadway, Baltimore, MD 21205.

19. This research was supported in part by Grants HD 1098105465 , NS 15829, GM 19100 and NS 13513-04 from the U.S. Public Health Service.

20. Received for publication August 27, 1981.

21. Accepted for publication November 13, 1981 